\title{
Treatment-Related Biomarkers in Pulmonary Hypertension
}

\author{
Aparna C. Swaminathan ${ }^{1,2}$, Alex C. Dusek ${ }^{1,2}$, and Tim J. McMahon ${ }^{1,2}$ \\ ${ }^{1}$ Duke University and Durham Department of Veterans Affairs Medical Centers, Durham, North Carolina; and ${ }^{2}$ Bayer HealthCare, \\ Whippany, New Jersey
}

\begin{abstract}
Significant advances in the treatment of pulmonary arterial hypertension (PAH) over the last two decades have led to the introduction of multiple classes of oral therapy, but the disease remains devastating for many patients. Disease progression, in spite of oral monotherapy, is a major problem, and alternative therapy, such as infusion of prostacyclins, is cumbersome and carries considerable potential morbidity. Use of combination oral therapy, including drugs from both the endothelin receptor antagonist and phosphodiesterase- 5 inhibitor classes, has increased, and there is some evidence to support this approach. Given the multiple options now available in pulmonary hypertension $(\mathrm{PH})$ therapy, biomarkers to guide treatment decisions could be helpful. Here, we review the evidence for and against the clinical use of molecular biomarkers relevant to $\mathrm{PH}$ pathogenesis, emphasizing assayable markers that may also inform more rational selection of agents that influence pathways targeted by treatment. We emphasize the interactive nature of changes in mediators and messengers, such as endothelin-1, prostacyclin, brain natriuretic peptide (which has demonstrated biomarker utility), nitric oxide derivatives, and cyclic guanosine
\end{abstract}

monophosphate, which play important roles in processes central to progression of PAH, such as vascular remodeling, vasoconstriction, and maladaptive right ventricular changes, and are relevant to its therapy. Accordingly, we propose that the identification and use of a molecular biomarker panel that assays these molecules in parallel and serially might, if validated, better inform unique patient phenotypes, prognosis, and the rational selection and titration of combination oral and other therapy in individual patients with $\mathrm{PH} / \mathrm{PAH}$.

Keywords: right ventricle; endothelin; nitric oxide; biomarker

\section{Clinical Relevance}

Multiple classes of therapy exist now for pulmonary hypertension, but outcomes remain disappointing. Prospective identification of biomarkers that can help guide decision making are needed. We review treatment-related candidate biomarkers and their interactions in light of the emerging adoption of combination therapy.
Pulmonary hypertension $(\mathrm{PH})$ is a progressive, fatal disease characterized by elevated pulmonary arterial pressure and secondary right ventricular (RV) dysfunction. PH may arise idiopathically (known as idiopathic pulmonary arterial hypertension [iPAH]) or due to certain associated conditions (such as connective tissue disease, anorexigen use, human immunodeficiency virus [HIV], et cetera; collectively, group I). PAH affects between 5 and 15 people per 1 million adults in the general population $(1,2)$. Far more commonly, $\mathrm{PH}$ can arise in the setting of chronic heart, lung, or thromboembolic disease, representing PH categories II-IV, respectively, as classified by consensus and referred to as World Health Organization (WHO) groups $(3,4)$. The pathogenesis of $\mathrm{PAH}$ is highly complex and characterized by pulmonary endothelial cell (EC) dysfunction, imbalance of vasoactive (and vasoproliferative) mediators, oxidative stress, metabolic dysregulation, fibrosis, and inflammation (5). Mutations in bone morphogenetic protein receptor II have been estimated to underlie a subset of familial and idiopathic cases of PAH $(6,7)$. However, these mutations and exposures account for only a fraction of cases, and the

(Received in original form November 14, 2014; accepted in final form January 21, 2015)

This work was supported by Bayer HealthCare, National Institutes of Health grant HL107608, and Department of Veterans Affairs grant BX-000281.

A.C.S. designed the literature search, wrote the paper, and revised critically. A.C.D. conceived the work, wrote the paper, and revised critically. T.J.M.

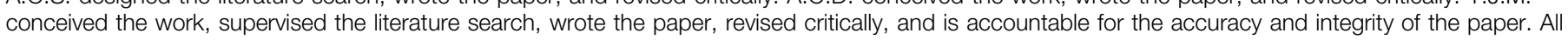
authors gave approval of the final version.

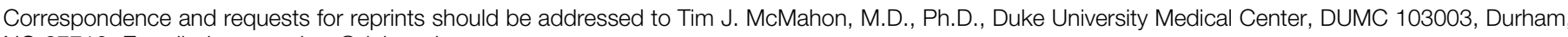
NC 27710. E-mail: tim.mcmahon@duke.edu

This article has an online supplement, which is accessible from this issue's table of contents at www.atsjournals.org

Am J Respir Cell Mol Biol Vol 52, Iss 6, pp 663-673, Jun 2015

Copyright (C) 2015 by the American Thoracic Society

Originally Published in Press as DOI: 10.1165/rcmb.2014-0438TR on January 22, 2015

Internet address: www.atsjournals.org 
disease process remains poorly understood. There is a pressing need to better characterize these patients to formulate prognosis, develop better and novel treatments, and to guide selection among existing therapies (3). Generation of biomarker knowledge from clinical trial data has been limited, in part because of lack of standardization of trial design, small study sizes, and limited longitudinal follow up.

\section{PAH and Its Treatment}

Dysregulation of multiple vasodilator/ antiproliferative and vasoconstrictor/ vasoproliferative mediators has been closely associated with the disease. Knowledge of these regulators has given rise to four main therapeutic classes specific to the treatment of PAH (Figure 1): prostacyclin agonists (epoprostenol, treprostinil, beraprost, and iloprost), endothelin (ET) receptor antagonists (ERAs; bosentan, ambrisentan, and macitentan), phosphodiesterase (PDE)-5 inhibitors (PDE5is; sildenafil or tadalafil), and soluble guanylate cyclase (sGC) stimulators (riociguat). In randomized, controlled trials, these agents promote improvements in symptoms, exercise tolerance, and hemodynamics, and retard disease progression (8-14). However, the response to any given treatment is not predictable, and outcomes in $\mathrm{PAH}$ remain suboptimal. For example, 3-year survival rates are only roughly $70 \%$, despite the availability of these multiple therapies (15). Because the literature lacks comparative clinical trials, an evidence-based approach to drug class selection has not been developed beyond a preference for oral agents in early to moderate disease and parenteral therapies in advanced disease (4). Therefore, treatment is typically selected empirically, and is influenced, as in other diseases, in part by an individual physician's perception of medication efficacy and side effects, and by the costs to the patient and payor coverage.

\section{PAH in the Era of Combination Oral Therapy}

As newer therapies for PAH emerge (i.e., riociguat, macitentan, oral treprostinil, and selexipag) (16), the

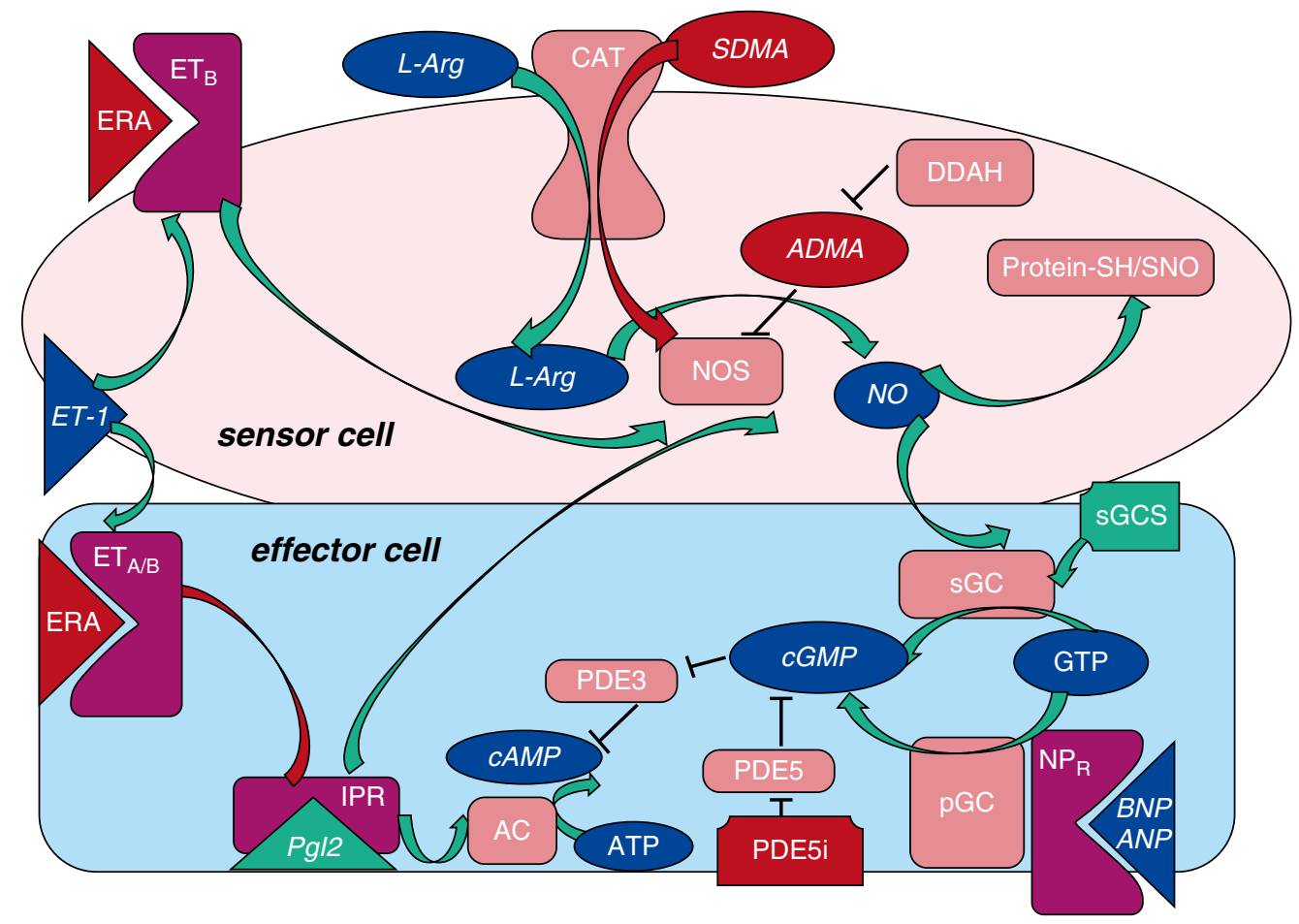

Figure 1. Vasoregulatory mediators and/or biomarkers relevant to current pulmonary arterial hypertension (PAH) therapy, and their interactions. Endogenous mediators (blue ovals), enzymes or other protein targets (both shown as pink rectangles), mediator-relevant drugs (green [stimulatory] or red [inhibitory]), and PAHassociated derangements are interconnected (also red). Mediators produced by a sensor cell may influence an adjacent or distant effector cell. Classically, this involves signaling by endothelial cells (ECs; "sensor cells") to influence "effector cells" (e.g., vascular smooth muscle cells [SMCs]), but, in PAH, many cell types are involved. Relevant mediators may act in an autocrine fashion also. The vasoconstrictor and mitogenic peptide, endothelin (ET)-1, acting at $E T_{A}$ or $E T_{B}$ receptors, is antagonized by ET-1 receptor antagonists (ERA). ECs also produce nitric oxide (NO) from the precursor amino acid, L-arginine (L-Arg); asymmetric dimethyl arginine (ADMA) and symmetric dimethyl arginine (SDMA) (red) may antagonize this. Levels of ADMA depend, in part, on its catabolism by dimethylarginine dimethylaminohydrolase (DDAH). Antiproliferative and pulmonary vasodilator actions of NO produced by lung ECs can be mediated by the activation of soluble guanylate cyclase (SGC) in, for example, vascular SMCs, or by more durable S-nitroso (SNO) modification (S-nitrosylation) of regulatory thiols (SH) on key proteins. Cyclic guanosine monophosphate (cGMP) formation from GTP is the result when SGC is stimulated by NO. Notably, brain natriuretic peptide (BNP; or atrial natriuretic peptide [ANP]) can also elicit the formation of cGMP from GTP via a membrane-bound GC enzyme (particulate GC), possibly contributing to the (paradoxically) elevated cGMP levels typical of advanced PAH. Other mediator interactions include prostacyclin receptor- and endothelin receptor (ETR)-triggered NO synthesis, and cyclic adenosine monophosphate (cAMP)/cGMP cross-talk via phosphodiesterases (PDEs). For example, PDE3 can catabolize either, while PDE5 is selective for cGMP. Mediators that are also potential or proven biomarkers are in italics. AC, adenylate cyclase; CAT, cationic amino acid transporter; $\mathrm{IPR}$, prostacyclin receptor; NOS, nitric oxide synthase; $\mathrm{NP}_{\mathrm{R}}$, natriuretic peptide receptor; pGC, particulate guanylate cyclase; Pgl2, prostacyclin. 
number of options for monotherapy and combination strategies is increasing. Both monotherapy strategies followed by addon therapy $(9,16-20)$, as well as initial ("up-front") double-therapy (21-23), have yielded mixed results compared with monotherapy in terms of the benefits of various combinations and/or agentsequencing strategies. In the midst of ambivalent data and the absence of clear treatment guidelines, it is important to identify more precise and rapidly available predictors of treatment response and prognosis. Objective biomarkers that indicate the disease stage (in addition to disease severity, as reflected by invasive hemodynamics) and response to therapeutic intervention would be useful tools for the management of PAH. Currently, a strong acute pulmonary vasodilator response to inhaled nitric oxide (NO) or prostacyclin remains the only established prognostic variable of treatment success leading to clear guidance: to select a high-dose calcium channel blocker as the treatment of choice. This small subset of patients with PAH can be more precisely phenotyped as "vasoreactive" early in the recommended algorithm, resulting in favorable long-term outcomes, but only about $10 \%$ of the $\mathrm{PAH}$ population shows vasoreactivity $(24,25)$. In other diseases, such as cancer and HIV/acquired immune deficiency syndrome, biomarkers have been used to better characterize the genotypic and/or phenotypic characteristics of a patient, which can, in turn, lead to more optimized treatment tailored to that individual patient (e.g., antiretroviral treatment resistance testing in HIV, human epidermal growth factor receptor 2 (HER2) in breast cancer) (26). Here, we discuss the potential for candidate biomarkers to play a similar role in $\mathrm{PAH}$, with a special emphasis on treatment decision making.

\section{Paucity of Existing Biomarkers in PAH}

The U.S. Food and Drug Administration defines a biomarker as a characteristic that is objectively measured and evaluated as an indicator of normal biologic processes, pathogenic processes, or biological responses to a therapeutic intervention (27). In addition, assays for a useful biomarker should be reproducible and cost-effective. Given the complexity of $\mathrm{PAH}$ and our incomplete understanding of its pathogenesis, numerous markers have been investigated for potential as biomarkers. Almost none of these, however, has been identified and validated as clinically relevant. This is likely due, in part, to small study sizes and lack of adequate power. In addition, $\mathrm{PAH}$ is a heterogeneous disease, and long-term data are limited. The only biomarker recommended by current guidelines for risk stratification is either brain natriuretic peptide (BNP) or the N-terminal fragment (NT) of pro-BNP (NT-proBNP) (28). Similarly, only BNP is cited in guidelines addressing PAH treatment endpoints: a "normal" BNP is suggested as a treatment goal (29).

\section{PAH Biomarkers Relevant to Therapy}

Although the development and characterization of PAH therapeutics have largely focused on only three discrete pathways, there is, in fact, rich cross-talk among these axes (as partially reflected in Figure 1), yielding multifactorial pathways and interrelated mediators worthy of targeting. For instance, preclinical evidence indicates a role for ET-1 itself in the response to PDE5is, sGCSs, ERAs, and prostacyclin agonists and their combinations $(30,31)$. One of the key features of PAH is endothelial dysfunction characterized by decreased endothelial NO production, and the centrality of $\mathrm{NO}$ deficiency in $\mathrm{PAH}$ has been discussed $(32,33)$. It is possible that biomarkers in the $\mathrm{NO} / \mathrm{sGC} /$ cyclic guanosine monophosphate (cGMP) or related ET or prostanoid/cyclic adenosine monophosphate (cAMP) axes may help characterize, more objectively, the stage or severity of PAH and predict optimal therapy for maximal treatment response, given that the currently available oral therapies for $\mathrm{PAH}$ act directly upon these same targets. General reviews discussing biomarkers in pulmonary diseases have been published previously (34-39). This review focuses on the potential utility of ET-1-related, NO/sGC/cGMP-related, and other serologic biomarkers in decision making in the treatment of PAH. The role of these biomarkers in prognosis or correlation with important clinical endpoints is addressed secondarily; however, their role in screening and detection are beyond the scope of this review. Much of our understanding of these mediators (and potential biomarkers) has focused on the abnormal ECs and smooth muscle cells (SMCs) of the vascular wall in PAH. However, these molecules can also transduce intercellular and intracellular signaling involving a wide variety of cell types that may contribute to the development and progression of $\mathrm{PAH}$ and its consequences, including the pericyte, lymphocyte, macrophage, fibroblast and myofibroblast, endothelial progenitor cell, and of course, the cardiomyocyte (40-43).

\section{NO}

NO is an important endogenous vasodilator and antiproliferative agent, and acts, in part, through the activation of sGC to generate cGMP. NO is synthesized from $\mathrm{L}$-arginine and oxygen $\left(\mathrm{O}_{2}\right)$ via a multistep reaction catalyzed by endothelial NO synthases (eNOSs). Recently, it has been discovered that NO can alternatively be produced via the reduction of the anion nitrite $\left(\mathrm{NO}_{2}{ }^{-}\right)$by multiple proteins, including hemoglobin $(\mathrm{Hb})$, myoglobin, and xanthine oxidase $(44,45) . \mathrm{NO}_{2}^{-}$reduction is favored under hypoxia, which is coincidentally when endogenous formation of NO from NOS is impaired $(45,46)$. The reduction of eNOS expression in the lungs of patients with $\mathrm{PAH}$ supports the concept of deficient $\mathrm{NO}$ as a pathogenic factor in $\mathrm{PAH}$ (32). However, others have observed a regional distribution of eNOS enzyme notable for high levels in the plexiform lesions of patients with PAH (47).

\section{Asymmetric and Symmetric Dimethylarginines}

Asymmetric dimethyl arginine (ADMA) and symmetric dimethyl arginine (SDMA) are methylarginines that inhibit NO synthesis. ADMA blunts NO synthesis by competing with $\mathrm{L}$-arginine for eNOS binding sites, whereas SDMA interferes with intracellular arginine uptake. Both ADMA and SDMA are known to be elevated in the serum of patients with group I PAH compared with control subjects $(48,49)$. 
Table 1. Biomarker Correlations with Clinical Endpoints and Prognosis in Pulmonary Hypertension

\begin{tabular}{|c|c|c|c|c|c|}
\hline Biomarker & Population (WHO Group) & Patients (n) & Clinical Endpoint & Correlation & Reference \\
\hline eNO & I-IV & 41 & $\begin{array}{l}\text { PAP } \\
\text { Cl } \\
\text { RVSP (1 yr later) }\end{array}$ & Yes & (59) \\
\hline SNO & 1 & 14 & $\begin{array}{l}\text { PAP } \\
\text { PVR }\end{array}$ & Yes & (65) \\
\hline ADMA & 1 & 57 & $\begin{array}{l}\mathrm{MVO}_{2} \\
\mathrm{RAP} \\
\mathrm{Cl} \\
\text { Mortality }\end{array}$ & Yes & (49) \\
\hline ADMA & IV & 135 & $\begin{array}{l}\mathrm{Sv}_{\mathrm{O}_{2}} \\
\mathrm{RAP} \\
\mathrm{Cl}\end{array}$ & Yes & (50) \\
\hline Urine cGMP & 1 & 19 & $\begin{array}{l}\mathrm{Sv}_{\mathrm{O}_{2}} \\
\mathrm{Cl}\end{array}$ & Yes & (68) \\
\hline Plasma cGMP & I-IV & 13 & $\begin{array}{l}\text { PVR } \\
\text { Cl } \\
\text { PCWP }\end{array}$ & Yes & (72) \\
\hline ANP & 1 & 9 & $\begin{array}{l}\mathrm{PCWP} \\
\mathrm{Cl}\end{array}$ & No & (76) \\
\hline ANP & I, III-V & 18 & $\begin{array}{l}\text { Mean PAP } \\
\text { PCWP } \\
\text { PVR } \\
\text { RAP } \\
\text { Sv }_{\mathrm{O}_{2}}\end{array}$ & $\begin{array}{l}\text { No } \\
\text { Yes }\end{array}$ & (69) \\
\hline BNP & IV & 34 & PVR & Yes & (78) \\
\hline BNP & 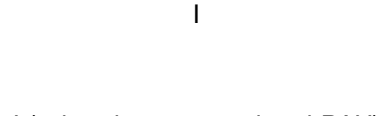 & 394 & $\begin{array}{l}\text { 6MWD } \\
\text { Clinical worsening } \\
\text { WHO functional class } \\
\text { Borg dyspnea score }\end{array}$ & Yes & (14) \\
\hline NT-proBNP & I (scleroderma-associated PAH) & 68 & $\begin{array}{l}\text { Mean PAP } \\
\text { PVR } \\
\text { 6MWD } \\
\text { Mortality }\end{array}$ & Yes & (79) \\
\hline NT-proBNP & I, III-V & 118 & $\begin{array}{l}\text { Mean PAP } \\
\text { PVR } \\
\text { RAP } \\
\text { CO } \\
\text { Cl } \\
\text { Mortality }\end{array}$ & Yes & (80) \\
\hline NT-proBNP & 1 & 198 & $\begin{array}{l}\text { Mortality } \\
6 \mathrm{MWD} \\
\text { WHO functional class }\end{array}$ & Yes & (83) \\
\hline ET-1 & I, III & 7 & Mean PAP during hypoxia & Yes & (88) \\
\hline ET-1 & 1 & 21 & $\begin{array}{l}\text { RAP } \\
\text { PA oxygen saturation }\end{array}$ & Yes & (91) \\
\hline ET-1 & I, V & 33 & $\begin{array}{l}\text { RAP } \\
\text { Indexed PVR } \\
\mathrm{CI} \\
\mathrm{SV}_{\mathrm{O}_{2}} \\
6 \mathrm{MWD} \\
\mathrm{NYHA} \text { functional class } \\
\text { Time to transplant or death }\end{array}$ & No & (92) \\
\hline ET-1 & 1 & 16 & $\begin{array}{l}\text { PVR } \\
\text { Mean PAP } \\
\text { CO } \\
\text { CI } \\
\text { 6MWD }\end{array}$ & Yes & (93) \\
\hline RDW & $I-V$ & 162 & $\begin{array}{l}\text { Mortality } \\
\text { Mean RAP } \\
\text { Mean PAP } \\
\text { Cl } \\
\text { PCWP } \\
\text { PVR }\end{array}$ & $\begin{array}{l}\text { Yes } \\
\text { No }\end{array}$ & (97) \\
\hline RDW & 1 & 139 & $\begin{array}{l}\text { 6MWD } \\
\text { WHO functional class } \\
\text { Mean RAP } \\
\text { Cl } \\
\text { Survival }\end{array}$ & Yes & (98) \\
\hline
\end{tabular}

Definition of abbreviations: 6MWD, 6-minute-walk distance; ADMA, asymmetric dimethyl arginine; ANP, atrial natriuretic peptide; BNP, brain natriuretic peptide; Cl, cardiac index; $\mathrm{CO}$, cardiac output; cGMP, cyclic guanosine monophosphate; eNO, exhaled nitric oxide; ET, endothelin; $\mathrm{MVO}_{2}$, maximal oxygen consumption;

NT-proNBP, N-terminal fragment of pro-BNP; NYHA, New York Heart Association; PA, pulmonary arterial; PAH, pulmonary arterial hypertension; PAP, pulmonary artery pressure; PCWP, pulmonary capillary wedge pressure; PVR, pulmonary vascular resistance; RAP, right atrial pressure; RDW, red blood cell distribution width; RVSP, right ventricular systolic pressure (estimated by echocardiography); SNO, S-nitrosothiol; $\mathrm{Sv}_{\mathrm{O}_{2}}$, mixed venous hemoglobin oxygen saturation; WHO, World Health Organization. 
This may be related to a decrease in the enzyme that degrades ADMA, dimethylarginine dimethylaminohydrolase, in patients with PAH (48). In a study of 57 patients with group I PAH, ADMA correlated (Table 1) with right atrial pressure, mixed venous $\mathrm{O}_{2}$ saturation, and cardiac index (49). Furthermore, the study found that ADMA levels independently predicted survival in patients with idiopathic PAH (49). ADMA has also been shown to have prognostic significance in other disease processes. In patients with chronic thromboembolic PH (CTEPH), ADMA levels were elevated compared with healthy control subjects and correlated with mixed venous $\mathrm{O}_{2}$ saturation, right atrial pressure, and cardiac index (50). ADMA decreased in patients with CTEPH 12 months after pulmonary endarterectomy (50). Other groups have found that ADMA levels predict cardiovascular and overall mortality in patients with end-stage renal disease and coronary artery disease $(51,52)$. Future clinical trials to assess the relationship of ADMA levels to $\mathrm{PAH}$ treatment may be of value.

\section{NO and Exhaled NO in PAH}

The half-life of NO itself in biological fluids is variable, but typically between 0.1 and 5 seconds, thus limiting its use as a potential biomarker. Previous animal studies have suggested that end-exhaled NO represents NO production from the pulmonary circulation (53). Whereas some have demonstrated local underproduction of $\mathrm{NO}$ in exhaled airway gas from patients with $\mathrm{PAH}$ (54-56), others have demonstrated normal values (57). A study of nine patients with PAH secondary to left-toright intracardiac shunts found similar baseline exhaled NO (eNO) values in patients and control subjects, but 18 hours after inhaled epoprostenol, eNO values were increased in patients compared with control subjects (58). Another group found that treatment with IV epoprostenol increased eNO levels in patients with both primary and secondary PAH after 24 hours (59). This did not reliably correlate with immediate hemodynamic changes (Table 2), although most patients on epoprostenol had a decreased RV systolic pressure after 12 months of therapy (59). Girgis and colleagues
(60) found that eNO levels were decreased in 10 patients with WHO group I PAH compared with control subjects. After treatment for 3 months with the ERA, bosentan, eNO levels increased and were similar to those of control subjects (60).

\section{NO Metabolites: $\mathrm{NO}_{2}{ }^{-}$and Nitrate}

$\mathrm{NO}$ rapidly oxidizes into $\mathrm{NO}_{2}{ }^{-}$and nitrate $\left(\mathrm{NO}_{3}{ }^{-}\right)$, which are collectively referred to as $\mathrm{NO}$ metabolites (NOx). There has been interest in the measurement of $\mathrm{NOx}$ as a surrogate of in vivo $\mathrm{NO}$ activity (61). However, these metabolites are significantly affected by dietary factors (62) and glomerular filtration (63). Reported plasma NOx levels in patients with PAH have been variable $(41,57,60$, 64), but urinary NOx was found to be lower in patients with $\mathrm{PAH}$ on an $\mathrm{NO}_{3}{ }^{-}$/ $\mathrm{NO}_{2}{ }^{-}$-restricted diet (60). The group also found an increase in urinary NOx with bosentan therapy (60). However, current studies unfortunately do not link either NOx or exhaled NO to clinical outcomes or serve in a predictive fashion to help guide therapeutic decision making. Further investigation must be performed to characterize the potential role of these biomarkers in assessing severity and response to treatment in $\mathrm{PAH}$.

\section{Red Blood Cell S-Nitrosothiols}

NO binds reversibly to a reactive thiol sulfur of the Cys $\beta 93$ cysteine residue of the $\mathrm{Hb} \beta$ globin chain, forming an S-nitrosothiol (SNO)-Hb (SNO-Hb). The SNO side group, a durable and bioactive derivative of $\mathrm{NO}$, is effectively released and exported from the red blood cell (RBC) in small amounts to effect intercellular signaling when deoxygenation triggers the conformational switch in $\mathrm{Hb}$ from the oxygenated " $R$ " structure to the deoxygenated " $T$ " structure, in which $\mathrm{NO} / \mathrm{SNO}$ binding is no longer favored. In this way, the $\mathrm{RBC} \mathrm{Hb}$ is able to couple the demand for regional increases in blood flow with the $\mathrm{O}_{2}$ needs of the tissue (46). Patients with advanced PAH had decreased RBC SNO (65). Furthermore, administration of ethyl $\mathrm{NO}_{2}{ }^{-}$to patients with $\mathrm{PAH}$ restored $\mathrm{RBC} \mathrm{SNO}-\mathrm{Hb}$ levels to the normal range along with immediate improvements in RBC-dependent vasoactivity, pulmonary vascular resistance (PVR), and blood $\mathrm{O}_{2}$ uptake by the lung (65). The concentrations of SNO-Hb and NOx increased after inhaled NO therapy in infants with persistent $\mathrm{PH}$ of the newborn (64). This supports the concept that SNO$\mathrm{Hb}$ is a vehicle for extrapulmonary actions of inhaled NO (66). Larger studies are needed to determine the utility of RBC $\mathrm{SNO}$ as a PAH biomarker that predicts disease severity and/or response to treatment.

\section{cGMP}

cGMP is the product of GC, which is present intracellularly in two forms: a cytosolic form activated by $\mathrm{NO}$, and a membrane-bound form activated by members of the natriuretic peptide family. It is an intracellular second messenger in platelets, vascular smooth muscle, and other cells that can also be measured in the circulation. Several groups have found that plasma levels of cGMP correlate with levels of natriuretic peptides in patients with heart failure (67). Urinary cGMP levels are higher in patients with $\mathrm{PAH}$ compared with healthy control subjects or patients with asthma, and correlated inversely with cardiac index (68). Another study found elevated plasma cGMP levels in patients with PAH compared with control subjects, which also correlated with atrial natriuretic peptide (ANP) levels (69). The elevated cGMP in group I PAH presumably reflects GC activation by BNP and/or ANP, rather than by bioactive $\mathrm{NO}$ and its derivatives, which may be depressed in PAH (70). Indeed, the natriuretic peptide receptors couple to particulate (membrane-bound) GC (see Figure 1), and cGMP elevations via particulate GC stimulation may therefore act quite differently from sGC-induced cGMP elevations. The PDE5is (e.g., sildenafil) act by inhibiting the degradation of cGMP (Table 3), prolonging its bioavailability, thereby promoting vasodilation and blunting vascular remodeling. PDE5 expression is increased in $\mathrm{PAH}$, and its expression/activity is up-regulated in the abnormal RV cardiomyocyte as compared with healthy individuals (71). A study of 13 patients with $\mathrm{PAH}$ demonstrated an increase in plasma cGMP levels immediately after treatment with sildenafil 
Table 2. Treatment-Related Biomarker Changes in Pulmonary Hypertension

\begin{tabular}{|c|c|c|c|c|c|}
\hline Therapy & $\begin{array}{l}\text { Population WHO } \\
\text { Group (n) }\end{array}$ & $\begin{array}{l}\text { Biomarker } \\
\text { (Change) }\end{array}$ & Assay Method & Clinical Endpoint & Ref. \\
\hline Prostanoid: epoprostenol & I-V (9) & eNO (increased) & Chemiluminescence & RVSP: acute decrease & (59) \\
\hline Prostanoid: iloprost & I, III, IV (18) & cGMP (decreased) & Radioimmunoassay & $\begin{array}{l}\text { PVR: acute decrease } \\
\text { mPAP: acute decrease }\end{array}$ & (69) \\
\hline Prostanoid: iloprost & I, III, IV (18) & ANP (decreased) & Radioimmunoassay & $\begin{array}{l}\text { PVR: acute decrease } \\
\text { mPAP: acute decrease }\end{array}$ & (69) \\
\hline $\begin{array}{l}\text { Prostanoid: inhaled } \\
\text { treprostinil in addition } \\
\text { to bosentan or sildenafil }\end{array}$ & I (235) & $\begin{array}{l}\text { NT-proBNP } \\
\text { (decrease) }\end{array}$ & Not specified & 6MWD: increase & (18) \\
\hline ERA: bosentan & I (10) & $\begin{array}{l}\text { eNO and urine } \\
\text { NOx } \\
\text { (both increased) }\end{array}$ & Urine NOx: chemiluminescence & 6MWD: increase at 3 mos. & (60) \\
\hline ERA: ambristentan & I (192) & BNP (decrease) & & $\begin{array}{l}\text { 6MWD: increase } \\
\text { Time to clinical worsening: } \\
\text { improve } \\
\text { Borg dyspnea score: } \\
\text { improvement } \\
\text { WHO functional class: } \\
\text { improvement }\end{array}$ & (14) \\
\hline sGC stimulator: riociguat & I (443) & $\begin{array}{l}\text { NT-proBNP } \\
\text { (decrease) }\end{array}$ & Not specified & $\begin{array}{l}\text { 6MWD: increase } \\
\text { PVR: acute decrease } \\
\text { WHO functional class: } \\
\text { improvement } \\
\text { Time to clinical worsening: } \\
\text { improvement }\end{array}$ & (16) \\
\hline sGC stimulator: riociguat & IV (261) & $\begin{array}{l}\text { NT-proBNP } \\
\text { (decrease) }\end{array}$ & Not specified & $\begin{array}{l}\text { 6MWD: increase } \\
\text { PVR: acute decrease } \\
\text { WHO functional class: } \\
\text { improvement }\end{array}$ & (85) \\
\hline NO/SNO donor: ethyl nitrite & I (9) & RBC SNO & Photolysis-chemiluminescence & $\begin{array}{l}\text { PVR: acute decrease } \\
\mathrm{Sa}_{\mathrm{O}_{2}}: \text { acute increase }\end{array}$ & (65) \\
\hline PDE5 inhibitor: sildenafil & I (13) & cGMP (increased) & ELISA & $\begin{array}{l}\text { PVR: decrease cardiac } \\
\text { index: increase }\end{array}$ & (72) \\
\hline $\begin{array}{l}\text { Pulmonary } \\
\text { thromboendarterectomy }\end{array}$ & IV (135) & ADMA (decrease) & HPLC & $\begin{array}{l}\text { Survival after pulmonary } \\
\text { thromboend-arterectomy }\end{array}$ & (50) \\
\hline $\begin{array}{l}\text { Pulmonary } \\
\text { thromboendarterectomy }\end{array}$ & IV (34) & BNP (decrease) & Radioimmunoassay & PVR: decrease & (78) \\
\hline
\end{tabular}

Definition of abbreviations: ERA, ET-1 receptor antagonist; mPAP, mean pulmonary arterial pressure; NO, nitric oxide; NOx, NO metabolites; PDE, phosphodiesterase; $\mathrm{RBC}$, red blood cell; $\mathrm{Sa}_{\mathrm{O}_{2}}$, arterial oxygen saturation; $\mathrm{SGC}$, soluble guanylate cyclase.

and inhaled NO (72). This correlated with a decrease in PVR and increase in cardiac index (72). A study of 18 patients with $\mathrm{PAH}$ identified an immediate decrease in cGMP levels after iloprost inhalation, along with reductions in PVR and pulmonary artery pressure (PAP) (69). Thus, cGMP may be sensitive not only to NO and its derivatives, but also to prostanoids, with negative feedback, for example. Further investigation and longer follow up are necessary to better understand the role and responses of cGMP and its potential to individualize treatment decisions.

\section{CAMP}

In response to binding of prostacyclin to its receptor, adenylate cyclase is activated, leading to increased production of the second messenger cAMP in various cell types, including those responsible for the modulation of vascular remodeling in PAH. For example, intracellular cAMP in human pulmonary arterial SMCs is elevated by the approved prostacyclin analogs, iloprost and treprostinil (73). Similarly, platelet cAMP was doubled by infusion of iloprost in healthy male volunteers (74). The role of cAMP and the case for its potential utility in guiding therapeutic decision making in $\mathrm{PAH}$, therefore, have substantial homology to that of cGMP. In fact, a case can be made for examining the two mediators in concert, because of the potential for crosstalk between cAMP and cGMP, in that certain enzymes responsible for their degradation (PDEs) are shared.

\section{NT-ProBNP and the $\mathbf{N}$ Terminal of ANP}

Natriuretic peptides were among the first biomarkers identified in patients with PAH. BNP is a natriuretic hormone released primarily from the heart (particularly the ventricles) due to myocardial strain (75). The main action of BNP is natriuresis and vasodilation via the renin/angiotensin pathway. The prohormone, proBNP, is split into BNP and the inactive metabolite, NT-proBNP. ANP is a peptide hormone secreted from cardiac atria in response to increased atrial pressure, as is the NT of ANP (NT-ANP).

ANP levels were elevated in a small group of patients with $\mathrm{PAH}$ compared with healthy control subjects, but did not 
Table 3. Current Therapeutic Classes in Pulmonary Hypertension and Relation to Selected Molecular Biomarkers

Therapeutic Class

Targeted PH Dysfunction

\section{Desired Mechanistic Result}

\begin{tabular}{llll} 
Stimulators & $\begin{array}{l}\text { Prostacyclin analogs } \\
\text { SGC stimulators }\end{array}$ & $\begin{array}{c}\text { Decreased adenylate cyclase stimulation by } \\
\text { upstream prostacyclin }\left(\mathrm{Pgl}_{2}\right) \\
\text { Decreased sGC stimulation by upstream NO }\end{array}$ & $\begin{array}{c}\text { Restore cAMP signaling } \\
\text { Restore cGMP signaling by stimulating its } \\
\text { production }\end{array}$ \\
Inhibitors & $\begin{array}{l}\text { ET-1 receptor antagonists } \\
\text { PDE5 inhibitors }\end{array}$ & $\begin{array}{l}\text { Increased expression and/or activity of ET-1 } \\
\text { Increased expression and/or activity of PDE } \\
\text { with degradation of cGMP }\end{array}$ & $\begin{array}{c}\text { Blocks harmful effects of ET-1 } \\
\text { Prevent harmful effects of PDE } \\
\text { cGMP }\end{array}$ \\
\hline
\end{tabular}

Definition of abbreviations: cAMP, cyclic adenosine monophosphate; $\mathrm{PH}$, pulmonary hypertension.

change immediately after prostacyclin infusion (76). Wiedemann and colleagues (69) identified significantly elevated baseline ANP levels in patients with PAH compared with control subjects. Levels correlated with baseline right atrial pressure, PVR, and mixed venous $\mathrm{O}_{2}$ saturation of $\mathrm{Hb}$ (69). Moreover, treatment of patients with PAH with inhaled iloprost acutely decreased ANP levels, which correlated with decreases in mean PAP and PVR (69).

Compared with ANP, BNP is much more stable and is less sensitive to temperature changes, making it a more practical test (77). NT-proBNP has an advantage over BNP in that its metabolic clearance is slower. Similar to ANP, BNP and NT-proBNP correlate with hemodynamic parameters (including mean PAP and PVR) and the severity of $\mathrm{PH}(69,78-80)$. Baseline levels of both BNP and NT-proBNP also predict mortality in patients with PAH (79-82). Furthermore, serial decreases in BNP or NT-proBNP predict survival, and serial increases predict mortality (83). In adult patients with sickle cell disease and $\mathrm{PAH}$, NT-proBNP is an independent predictor of mortality (84).

BNP and NT-proBNP levels have also been assessed as reporters of the response to therapy. Addition of inhaled trepostinil to bosentan or sildenafil for 12 weeks decreased NT-proBNP levels and increased 6-minute walk distance (6MWD) (18). BNP levels also decreased after 12 weeks of therapy with ambrisentan (14).

Furthermore, in patients with CTEPH, BNP decreased significantly 1 month after pulmonary thromboendarterectomy, a change that correlated with the change in total PVR (78). Treatment with the sGC stimulator, riociguat, led to significant reductions in NT-proBNP versus placebo in studies of patients with PAH (16) and those with inoperable/residual CTEPH (85).

In summary, the natriuretic peptides are important biomarkers in PAH. BNP's value as a biomarker in $\mathrm{PAH}$ may be primarily as an indicator of right heart failure rather than underlying $\mathrm{PAH}$ pathogenesis. Indeed, because RV function is a central determinant of $\mathrm{PAH}$ outcome, there is a pressing need to advance the understanding of the determinants of adaptive versus maladaptive right heart remodeling in $\mathrm{PAH}$, and related biomarkers may help identify these patients to tailor therapy. BNP and ANP stimulate the production of cGMP (a likely contributor to the high baseline cGMP in patients with severe PAH) (70), and the elevated cGMP may help to protect the right heart (86). Prospective studies are necessary to help determine the clinical significance of thresholds for BNP, assayed alone or in concert with cGMP, in individual patients.

\section{ET-1 and C-Terminal-proET-1}

ET-1 is a potent vasoconstrictor and stimulates proliferation of pulmonary artery SMCs. It is produced by the endothelium through cleavage of the biologically inactive precursor, big ET-1, by ET-converting enzyme. Big ET-1 might be a more reliable biomarker, because of its longer circulating half-life (87). Two subtypes of $\mathrm{ET}$ receptor, $\mathrm{ET}_{\mathrm{A}}$ and $\mathrm{ET}_{\mathrm{B}}$, mediate the biological actions of ET- 1 . $\mathrm{ET}_{\mathrm{A}}$ receptors are expressed on SMCs and cardiac myocytes, whereas $\mathrm{ET}_{\mathrm{B}}$ receptors are expressed on SMCs and vascular ECs. Activation of $\mathrm{ET}_{\mathrm{A}}$ and $\mathrm{ET}_{\mathrm{B}}$ receptors on
SMCs cause vasoconstriction, cell proliferation, and hypertrophy, whereas activation of $\mathrm{ET}_{\mathrm{B}}$ receptors on $\mathrm{ECs}$ promote clearance of ET-1 from the circulation and results in the release of vasodilators with antiproliferative properties, such as NO and prostacyclin. This is significant, because, whereas bosentan antagonizes both $\mathrm{ET}_{\mathrm{A}}$ and $\mathrm{ET}_{\mathrm{B}}$ (Table 3), ambrisentan selectively antagonizes $\mathrm{ET}_{\mathrm{A}}$. Although this distinction has not translated into dramatic differences in clinical responses to $\mathrm{ET}_{\mathrm{A}}$-specific (versus nonspecific) monotherapy, it is possible that, in the setting of combination therapy, particularly with a PDE5i or sGCS, the clinical benefits of sparing the $\mathrm{ET}_{\mathrm{B}}$ receptor may be unmasked (23).

Plasma ET-1 is elevated in patients with $\mathrm{PAH}$ and correlated with gas exchange and hemodynamic indices (88-92). Levels of both ET-1 and its precursor, big ET-1, were correlated with PVR, mean PAP, cardiac output, cardiac index, and 6MWD (93). Levels of ET-1 also correlated with right atrial pressure, indexed PVR, cardiac index, and mixed venous $\mathrm{O}_{2}$ saturation, but not with New York Heart Association (NYHA) functional class or time to transplant or death (92). In an exploratory analysis, the ET-1 precursor, C-terminal (CT)-proET1 , provided prognostic data independent of that from other commonly used biomarkers (94).

\section{Interactions of ET-1 with NO or Prostanoids}

The ability of ET-1 to stimulate NO production may have particular impact when ERAs are administered. In the presence of $\mathrm{ET}_{\mathrm{A}}$ receptor inhibition, ET-1 
increases, reflecting a feedback regulation loop. The greater circulating ET-1 may then elicit increased NO production via the unblocked $\mathrm{ET}_{\mathrm{B}}$ receptors without influencing the (inhibited) $\mathrm{ET}_{\mathrm{A}}$ receptors (95). In rat pulmonary arteries preconstricted by ET-1, vasorelaxation induced by varying $\left(\mathrm{ET}_{\mathrm{A}}\right.$-specific and nonspecific) ERAs was similar (31).

However, the relaxation in response to ambrisentan was synergistic with that in response to the sGC stimulator, riociguat, whereas the sGC stimulator did not synergize with the nonspecific ERAs, consistent with an important role for $\mathrm{ET}_{\mathrm{B}}$-mediated NO production by $\mathrm{ET}-1$. The vasodilatory effect induced by $\mathrm{ET}_{\mathrm{A}}$ receptor blockade was essentially abolished by infusion of the NOS inhibitor, L-NAME, whereas prostacyclin inhibition did not impact the response in healthy humans (96). The antiproliferative effects of therapeutics targeting the prostacyclin, ET-1, and NO/ cGMP pathways may also interact. Patel and colleagues (30) found that the proliferation of distal pulmonary artery SMCs obtained from patients with $\mathrm{PAH}$ was inhibited by the prostacyclin analog, treprostinil, and the effect was additive with that elicited by a PDE5i or a sGCS (i.e., cGMP-elevating agents). In contrast, the antiproliferative effect of treprostinil was actually attenuated in the presence of dual-receptor ERAs, bosentan or macitentan. Given the network of potential interactions among these therapy-related biomarkers, it is rational to posit that simultaneous assay of players in the prostacyclin, ET-1, and L-arginine/ NO/cGMP pathway may better inform the selection of therapy in appropriate patients.

\section{RBC Distribution Width}

RBC distribution width (RDW) indicates the variability in the size of RBCs, and is routinely reported in automated complete blood counts. RDW was shown retrospectively to independently predict survival in $\mathrm{PAH}$, and even outperformed NT-proBNP in one cohort (97). RDW also predicted survival independently of 6MWD and NT-proBNP (98), and predicted survival in left heart failure, coronary artery disease, and renal disease (99).

\section{Other Molecular Biomarkers in PAH}

See the online supplement for a current review of additional circulating biomarkers of potential utility in $\mathrm{PAH}$ prognosis or decision making, but not necessarily directly related to treatment pathways.

\section{Conclusions and Future Directions}

Numerous circulating biomarkers have shown at least promise for informing clinical prognosis, guiding therapeutic decisions, and/or providing other unique information relevant to patients with $\mathrm{PH}$. Candidate biomarkers, even when intimately related to the disease process and its treatment, may prove to be useless clinically when tested. Several criteria should be met before a candidate biomarker, or biomarker panel, is considered clinically useful and worthy of a change in practice, or even inclusion as a study endpoint. These criteria include general and interlaboratory reproducibility, relevance to the disease process (and ideally to its therapy too, in this case), cost effectiveness, and validation, preferably with good external validity as well. In the case of the serologic biomarkers discussed here, existing assays are largely feasible and measurements reproducible in clinical and research laboratories. Notably, some endothelium-derived species, such as $\mathrm{NO}$ derivatives $\left(\mathrm{NO}_{2}{ }^{-}\right.$, SNOs) and ET-1, require special handling (acquisition in $\mathrm{NO}_{2}{ }^{-}$-free plasticware) and short time to assay, respectively. Cost effectiveness has not been specifically studied, and is best assessed in larger studies validating their utility in, for example, phenotyping patients likely to respond to agent $\mathrm{A}$ ( or $\mathrm{A}+\mathrm{B}$ ) rather than agent $\mathrm{C}$.

Recent advances in $\mathrm{PAH}$ treatment include the addition of new therapeutic drug classes available for oral or inhaled administration, and the finding that upfront combination oral therapy-at least when the combination of tadalafil and ambrisentan is used-may be superior to initiation of either agent alone (23). In this new treatment era, it is rational to examine whether a panel of vascular biomarkers can prospectively identify those patients most likely to benefit from a given (upfront) dual, sequential (addon), or single-agent therapy regimen. Illustrating the web of related mediators, BNP elevation leads to increases in cGMP that may be adaptive; selective ERAs can preserve or even promote the generation of bioactive NO species. We therefore suggest a new approach in the quest for a clinically useful biomarker. In this era, a useful biomarker or biomarker panel needs to recognize the interactions among candidate mediators/potential serologic biomarkers, the sensitivity of these signals to therapy, and the emerging practice of upfront and other combination therapy. Accordingly, we are investigating, prospectively, the clinical utility of a panel of biomarkers that reflect or interact with the biological pathways targeted by prevalent therapies. Specifically, we are examining longitudinal changes in ET-1, NTproBNP, cGMP, and the NO derivatives, $\mathrm{NO}_{2}{ }^{-}, \mathrm{NO}_{3}{ }^{-}$, and $\mathrm{SNO}$ in patients with $\mathrm{PH}$ (from various WHO groups) on oral monotherapy or combination therapy, and in relationship to changes in clinical variables, such as $6 \mathrm{MWD}$ and hemodynamics. The goal is to identify biomarker signatures that might predict favorable responses to each of multiple therapies (or their combination), and subsequently test resulting hypotheses in future, larger studies. Indeed, interactions among those biomarkers associated with therapeutic targets are numerous and complex, suggesting that assaying them in a coordinated and longitudinal fashion is optimal. Because $\mathrm{PAH}$ is a rare disease, and given the substantial morbidity and mortality in spite of these advances in therapy, the identification of such biomarker tools is urgently needed to help optimize and individualize therapy.

Author disclosures are available with the text of this article at www.atsjournals.org.

Acknowledgments: The authors gratefully acknowledge Dr. Kishan Parikh for critically reviewing the manuscript, Dr. Victor Tapson for constructive discussions, and Mr. Casey Herbert for assistance with the illustration. 


\section{References}

1. Humbert M, Sitbon O, Chaouat A, Bertocchi M, Habib G, Gressin V, Yaici A, Weitzenblum E, Cordier JF, Chabot F, et al. Pulmonary arterial hypertension in France: results from a national registry. Am $J$ Respir Crit Care Med 2006;173:1023-1030.

2. Ling Y, Johnson MK, Kiely DG, Condliffe R, Elliot CA, Gibbs JS, Howard LS, Pepke-Zaba J, Sheares KK, Corris PA, et al. Changing demographics, epidemiology, and survival of incident pulmonary arterial hypertension: results from the pulmonary hypertension registry of the United Kingdom and Ireland. Am J Respir Crit Care Med 2012; 186:790-796.

3. Dweik RA, Rounds S, Erzurum SC, Archer S, Fagan K, Hassoun PM, Hill NS, Humbert M, Kawut SM, Krowka M, et al.; ATS Committee on Pulmonary Hypertension Phenotypes. An official American Thoracic Society statement: pulmonary hypertension phenotypes. Am J Respir Crit Care Med 2014;189:345-355.

4. Taichman DB, Ornelas J, Chung L, Klinger JR, Lewis S, Mandel J, Palevsky HI, Rich S, Sood N, Rosenzweig EB, et al. Pharmacologic therapy for pulmonary arterial hypertension in adults: CHEST guideline and expert panel report. Chest 2014;146:449-475.

5. Farber HW, Loscalzo J. Pulmonary arterial hypertension. N Engl J Med 2004;351:1655-1665.

6. Lane KB, Machado RD, Pauciulo MW, Thomson JR, Phillips III JA, Loyd JE, Nichols WC, Trembath RC; International PPH Consortium. Heterozygous germline mutations in BMPR2, encoding a TGF-beta receptor, cause familial primary pulmonary hypertension. Nat Genet 2000;26:81-84.

7. Deng Z, Haghighi F, Helleby L, Vanterpool K, Horn EM, Barst RJ, Hodge SE, Morse JH, Knowles JA. Fine mapping of PPH1, a gene for familial primary pulmonary hypertension, to a 3-cM region on chromosome 2q33. Am J Respir Crit Care Med 2000;161:1055-1059.

8. Archer SL, Michelakis ED. Phosphodiesterase type 5 inhibitors for pulmonary arterial hypertension. N Engl J Med 2009;361:1864-1871.

9. Galiè N, Brundage BH, Ghofrani HA, Oudiz RJ, Simonneau G, Safdar Z, Shapiro S, White RJ, Chan M, Beardsworth A, et al.; Pulmonary Arterial Hypertension and Response to Tadalafil (PHIRST) Study Group. Tadalafil therapy for pulmonary arterial hypertension. Circulation 2009;119:2894-2903.[Published erratum appears in Circulation 124:e279.]

10. Galiè N, Ghofrani HA, Torbicki A, Barst RJ, Rubin LJ, Badesch D, Fleming T, Parpia T, Burgess G, Branzi A, et al.; Sildenafil Use in Pulmonary Arterial Hypertension (SUPER) Study Group. Sildenafil citrate therapy for pulmonary arterial hypertension. $N$ Engl J Med 2005;353:2148-2157.

11. Olschewski H, Simonneau G, Galiè N, Higenbottam T, Naeije R, Rubin LJ, Nikkho S, Speich R, Hoeper MM, Behr J, et al.; Aerosolized lloprost Randomized Study Group. Inhaled iloprost for severe pulmonary hypertension. N Engl J Med 2002;347:322-329.

12. Barst RJ, Rubin LJ, Long WA, McGoon MD, Rich S, Badesch DB, Groves BM, Tapson VF, Bourge RC, Brundage BH, et al.; Primary Pulmonary Hypertension Study Group. A comparison of continuous intravenous epoprostenol (prostacyclin) with conventional therapy for primary pulmonary hypertension. N Engl J Med 1996;334: 296-301.

13. Rubin LJ, Badesch DB, Barst RJ, Galie N, Black CM, Keogh A, Pulido T, Frost A, Roux S, Leconte I, et al. Bosentan therapy for pulmonary arterial hypertension. N Engl J Med 2002;346:896-903.

14. Galiè N, Olschewski H, Oudiz RJ, Torres F, Frost A, Ghofrani HA, Badesch DB, McGoon MD, McLaughlin VV, Roecker EB, et al.; Ambrisentan in Pulmonary Arterial Hypertension, Randomized, Double-Blind, Placebo-Controlled, Multicenter, Efficacy Studies (ARIES) Group. Ambrisentan for the treatment of pulmonary arterial hypertension: results of the ambrisentan in pulmonary arterial hypertension, randomized, double-blind, placebo-controlled, multicenter, efficacy (ARIES) study 1 and 2. Circulation 2008;117: 3010-3019.

15. Benza RL, Miller DP, Barst RJ, Badesch DB, Frost AE, McGoon MD. An evaluation of long-term survival from time of diagnosis in pulmonary arterial hypertension from the REVEAL Registry. Chest 2012;142: 448-456.
16. Ghofrani HA, Galiè N, Grimminger F, Grünig E, Humbert M, Jing ZC, Keogh AM, Langleben D, Kilama MO, Fritsch A, et al.; PATENT-1 Study Group. Riociguat for the treatment of pulmonary arterial hypertension. N Engl J Med 2013;369:330-340.

17. Simonneau G, Rubin LJ, Galiè N, Barst RJ, Fleming TR, Frost AE, Engel PJ, Kramer MR, Burgess G, Collings L, et al.; PACES Study Group. Addition of sildenafil to long-term intravenous epoprostenol therapy in patients with pulmonary arterial hypertension: a randomized trial. Ann Intern Med 2008;149:521-530.

18. McLaughlin VV, Benza RL, Rubin LJ, Channick RN, Voswinckel R, Tapson VF, Robbins IM, Olschewski H, Rubenfire M, Seeger W. Addition of inhaled treprostinil to oral therapy for pulmonary arterial hypertension: a randomized controlled clinical trial. J Am Coll Cardiol 2010;55:1915-1922.

19. Tapson VF, Torres F, Kermeen F, Keogh AM, Allen RP, Frantz RP, Badesch DB, Frost AE, Shapiro SM, Laliberte K, et al. Oral treprostinil for the treatment of pulmonary arterial hypertension in patients on background endothelin receptor antagonist and/or phosphodiesterase type 5 inhibitor therapy (the FREEDOM-C study): a randomized controlled trial. Chest 2012;142:1383-1390.

20. Pulido T, Adzerikho I, Channick RN, Delcroix M, Galiè N, Ghofrani HA, Jansa P, Jing ZC, Le Brun FO, Mehta S, et al.; SERAPHIN Investigators. Macitentan and morbidity and mortality in pulmonary arterial hypertension. N Engl J Med 2013;369:809-818.

21. Humbert M, Barst RJ, Robbins IM, Channick RN, Galiè N, Boonstra A, Rubin LJ, Horn EM, Manes A, Simonneau G. Combination of bosentan with epoprostenol in pulmonary arterial hypertension: BREATHE-2. Eur Respir J 2004;24:353-359.

22. McLaughlin V, Channick R, Ghofrani H-A, LeMarie J-C, Naeije R, Packer M, Souza R, Tapson V, Tolson J, Hoeper M. Effect of bosentan and sildenafil combination therapy on morbidity and mortality in pulmonary arterial hypertension $(\mathrm{PAH})$ : results from the COMPASS-2 study [abstract]. Chest 2014;146:860A.

23. Galiè N, Barbera JA, Frost A. AMBITION: a randomised, multicentre study of first-line ambrisentan and tadalafil combination therapy in subjects with pulmonary arterial hypertension (PAH). Eur Respir J 2014; 44(Suppl 58):2916.

24. Rich S, Kaufmann E, Levy PS. The effect of high doses of calciumchannel blockers on survival in primary pulmonary hypertension. N Engl J Med 1992;327:76-81.

25. Sitbon O, Humbert M, Jaïs X, loos V, Hamid AM, Provencher S, Garcia G, Parent F, Hervé P, Simonneau G. Long-term response to calcium channel blockers in idiopathic pulmonary arterial hypertension. Circulation 2005;111:3105-3111.

26. Vogel CL, Cobleigh MA, Tripathy D, Gutheil JC, Harris LN, Fehrenbacher L, Slamon DJ, Murphy M, Novotny WF, Burchmore M, et al. Efficacy and safety of trastuzumab as a single agent in first-line treatment of HER2-overexpressing metastatic breast cancer. $J$ Clin Oncol 2002;20:719-726.

27. U.S. Food and Drug Administration. Development \& approval process (drugs): glossary. 2014 [updated 2014 Jan 28; accessed 2015 Feb 10]. Available from: http://www.fda.gov/drugs/ developmentapprovalprocess/ drugdevelopmenttoolsqualificationprogram/ucm284395.htm

28. Galiè N, Hoeper MM, Humbert M, Torbicki A, Vachiery JL, Barbera JA, Beghetti M, Corris P, Gaine S, Gibbs JS, et al.; Task Force for Diagnosis and Treatment of Pulmonary Hypertension of European Society of Cardiology (ESC); European Respiratory Society (ERS); International Society of Heart and Lung Transplantation (ISHLT). Guidelines for the diagnosis and treatment of pulmonary hypertension. Eur Respir J 2009;34:1219-1263.

29. McLaughlin W, Gaine SP, Howard LS, Leuchte HH, Mathier MA, Mehta S, Palazzini M, Park MH, Tapson VF, Sitbon O. Treatment goals of pulmonary hypertension. J Am Coll Cardiol 2013;62(25 suppl):D73-D81.

30. Patel JAAD, Nelsen AC, Silverstein AM, Clapp LH. Comparison of current therapies to inhibit endothelin-induced growth of pulmonary artery smooth muscle cells (PAMSCs) derived from patients with pulmonary arteiral hypertension. Eur Resp Society 2014;44:2355.

31. Liang F, Yang S, Fan P, Jiang Z, Gillies HC, Yao L, Belardinelli L. Ambrisentan and riociguat synergistically relax endothelin-induced 
contraction of rat pulmonary arteries [abstract]. Am J Respir Crit Care Med 2014;189:A3324.

32. Giaid A, Saleh D. Reduced expression of endothelial nitric oxide synthase in the lungs of patients with pulmonary hypertension. N Engl J Med 1995;333:214-221.

33. Klinger JR, Abman SH, Gladwin MT. Nitric oxide deficiency and endothelial dysfunction in pulmonary arterial hypertension. Am J Respir Crit Care Med 2013;188:639-646.

34. Cracowski JL, Leuchte HH. The potential of biomarkers in pulmonary arterial hypertension. Am J Cardiol 2012;110(6 suppl):32S-38S.

35. Foris V, Kovacs G, Tscherner M, Olschewski A, Olschewski H. Biomarkers in pulmonary hypertension: what do we know? Chest 2013;144:274-283.

36. Warwick G, Thomas PS, Yates DH. Biomarkers in pulmonary hypertension. Eur Respir J 2008;32:503-512.

37. Rafeq S, Shah AM, Preston IR. Biomarkers in pulmonary arterial hypertension. Int J Clin Pract Suppl 2009;162:36-41.

38. Heresi GA. Clinical perspective: biomarkers in pulmonary arterial hypertension. Int J Clin Pract Suppl 2011;169:5-7.

39. Kramer F, Dusek A. Biomarkers of lung tissue remodeling in pulmonary diseases: implications for clinical practice and research. Curr Respir Med Rev 2012;8:100-107.

40. Taraseviciene-Stewart L, Nicolls MR, Kraskauskas D, Scerbavicius R, Burns N, Cool C, Wood K, Parr JE, Boackle SA, Voelkel NF. Absence of $T$ cells confers increased pulmonary arterial hypertension and vascular remodeling. Am J Respir Crit Care Med 2007;175:1280-1289.

41. Diller GP, van Eijl S, Okonko DO, Howard LS, Ali O, Thum T, Wort SJ, Bédard E, Gibbs JS, Bauersachs J, et al. Circulating endothelial progenitor cells in patients with Eisenmenger syndrome and idiopathic pulmonary arterial hypertension. Circulation 2008;117:3020-3030.

42. Frid MG, Brunetti JA, Burke DL, Carpenter TC, Davie NJ, Reeves JT, Roedersheimer MT, van Rooijen N, Stenmark KR. Hypoxia-induced pulmonary vascular remodeling requires recruitment of circulating mesenchymal precursors of a monocyte/macrophage lineage. Am J Pathol 2006;168:659-669.

43. Rabinovitch M. Molecular pathogenesis of pulmonary arterial hypertension. J Clin Invest 2012;122:4306-4313.

44. Cosby K, Partovi KS, Crawford JH, Patel RP, Reiter CD, Martyr S, Yang BK, Waclawiw MA, Zalos G, Xu X, et al. Nitrite reduction to nitric oxide by deoxyhemoglobin vasodilates the human circulation. Nat Med 2003;9:1498-1505.

45. Luchsinger BP, Rich EN, Gow AJ, Williams EM, Stamler JS, Singel DJ. Routes to S-nitroso-hemoglobin formation with heme redox and preferential reactivity in the beta subunits. Proc Natl Acad Sci USA 2003;100:461-466.

46. Sonveaux P, Lobysheva II, Feron O, McMahon TJ. Transport and peripheral bioactivities of nitrogen oxides carried by red blood cell hemoglobin: role in oxygen delivery. Physiology (Bethesda) 2007;22:97-112.

47. Mason NA, Springall DR, Burke M, Pollock J, Mikhail G, Yacoub MH, Polak JM. High expression of endothelial nitric oxide synthase in plexiform lesions of pulmonary hypertension. J Pathol 1998;185:313-318.

48. Pullamsetti S, Kiss L, Ghofrani HA, Voswinckel R, Haredza P, Klepetko W, Aigner C, Fink L, Muyal JP, Weissmann N, et al. Increased levels and reduced catabolism of asymmetric and symmetric dimethylarginines in pulmonary hypertension. FASEB $J$ 2005;19: 1175-1177.

49. Kielstein JT, Bode-Böger SM, Hesse G, Martens-Lobenhoffer J, Takacs A, Fliser D, Hoeper MM. Asymmetrical dimethylarginine in idiopathic pulmonary arterial hypertension. Arterioscler Thromb Vasc Biol 2005; 25:1414-1418.

50. Skoro-Sajer N, Mittermayer F, Panzenboeck A, Bonderman D, Sadushi R, Hitsch R, Jakowitsch J, Klepetko W, Kneussl MP, Wolzt M, et al. Asymmetric dimethylarginine is increased in chronic thromboembolic pulmonary hypertension. Am J Respir Crit Care Med 2007;176:1154-1160.

51. Valkonen VP, Päivä H, Salonen JT, Lakka TA, Lehtimäki T, Laakso J, Laaksonen R. Risk of acute coronary events and serum concentration of asymmetrical dimethylarginine. Lancet 2001;358:2127-2128.

52. Zoccali C, Bode-Böger S, Mallamaci F, Benedetto F, Tripepi G, Malatino L, Cataliotti A, Bellanuova I, Fermo I, Frölich J, et al. Plasma concentration of asymmetrical dimethylarginine and mortality in patients with end-stage renal disease: a prospective study. Lancet 2001;358:2113-2117.

53. Cremona G, Higenbottam T, Takao M, Hall L, Bower EA. Exhaled nitric oxide in isolated pig lungs. J Appl Physiol (1985) 1995;78: 59-63.

54. Riley MS, Pórszász J, Miranda J, Engelen MP, Brundage B, Wasserman K. Exhaled nitric oxide during exercise in primary pulmonary hypertension and pulmonary fibrosis. Chest 1997;111:44-50.

55. Kaneko FT, Arroliga AC, Dweik RA, Comhair SA, Laskowski D, Oppedisano R, Thomassen MJ, Erzurum SC. Biochemical reaction products of nitric oxide as quantitative markers of primary pulmonary hypertension. Am J Respir Crit Care Med 1998;158:917-923.

56. Kharitonov SA, Cailes JB, Black CM, du Bois RM, Barnes PJ. Decreased nitric oxide in the exhaled air of patients with systemic sclerosis with pulmonary hypertension. Thorax 1997;52: 1051-1055.

57. Archer SL, Djaballah K, Humbert M, Weir KE, Fartoukh M, Dall'avaSantucci J, Mercier JC, Simonneau G, Dinh-Xuan AT. Nitric oxide deficiency in fenfluramine- and dexfenfluramine-induced pulmonary hypertension. Am J Respir Crit Care Med 1998;158: 1061-1067.

58. Forrest IA, Small T, Corris PA. Effect of nebulized epoprostenol (prostacyclin) on exhaled nitric oxide in patients with pulmonary hypertension due to congenital heart disease and in normal controls. Clin Sci (Lond) 1999;97:99-102.

59. Ozkan M, Dweik RA, Laskowski D, Arroliga AC, Erzurum SC. High levels of nitric oxide in individuals with pulmonary hypertension receiving epoprostenol therapy. Lung 2001;179:233-243.

60. Girgis RE, Champion HC, Diette GB, Johns RA, Permutt S, Sylvester JT. Decreased exhaled nitric oxide in pulmonary arterial hypertension: response to bosentan therapy. Am J Respir Crit Care Med 2005;172:352-357.

61. Rhodes P, Leone AM, Francis PL, Struthers AD, Moncada S, Rhodes $\mathrm{PM}$. The L-arginine:nitric oxide pathway is the major source of plasma nitrite in fasted humans. Biochem Biophys Res Commun 1995;209:590-596. [Published erratum appears in Biochem Biophys Res Commun 211:705.]

62. Wang J, Brown MA, Tam SH, Chan MC, Whitworth JA. Effects of diet on measurement of nitric oxide metabolites. Clin Exp Pharmacol Physiol 1997;24:418-420.

63. Wennmalm A, Benthin G, Edlund A, Kieler-Jensen N, Lundin S, Petersson AS, Waagstein F. Nitric oxide synthesis and metabolism in man. Ann N Y Acad Sci 1994;714:158-164.

64. Ibrahim YI, Ninnis JR, Hopper AO, Deming DD, Zhang AX, Herring JL, Sowers LC, McMahon TJ, Power GG, Blood AB. Inhaled nitric oxide therapy increases blood nitrite, nitrate, and S-nitrosohemoglobin concentrations in infants with pulmonary hypertension. $J$ Pediatr 2012;160:245-251.

65. McMahon TJ, Ahearn GS, Moya MP, Gow AJ, Huang YC, Luchsinger $\mathrm{BP}$, Nudelman R, Yan Y, Krichman AD, Bashore TM, et al. A nitric oxide processing defect of red blood cells created by hypoxia: deficiency of S-nitrosohemoglobin in pulmonary hypertension. Proc Natl Acad Sci USA 2005;102:14801-14806.

66. McMahon TJ, Doctor A. Extrapulmonary effects of inhaled nitric oxide: role of reversible S-nitrosylation of erythrocytic hemoglobin. Proc Am Thorac Soc 2006;3:153-160.

67. Hirata $Y$, Ishii $M$, Matsuoka $H$, Sugimoto $T$, lizuka $M$, Uchida $Y$, Serizawa T, Sato H, Kohmoto O, Mochizuki T, et al. Plasma concentrations of alpha-human atrial natriuretic polypeptide and cyclic GMP in patients with heart disease. Am Heart $J$ 1987;113: 1463-1469.

68. Bogdan M, Humbert M, Francoual J, Claise C, Duroux P, Simonneau G, Lindenbaum A. Urinary cGMP concentrations in severe primary pulmonary hypertension. Thorax 1998;53:1059-1062.

69. Wiedemann R, Ghofrani HA, Weissmann N, Schermuly R, Quanz K, Grimminger $F$, Seeger W, Olschewski $\mathrm{H}$. Atrial natriuretic peptide in severe primary and nonprimary pulmonary hypertension: response to iloprost inhalation. J Am Coll Cardiol 2001;38:1130-1136.

70. Potter LR, Abbey-Hosch S, Dickey DM. Natriuretic peptides, their receptors, and cyclic guanosine monophosphate-dependent signaling functions. Endocr Rev 2006;27:47-72. 
71. Nagendran J, Archer SL, Soliman D, Gurtu V, Moudgil R, Haromy A, St Aubin C, Webster L, Rebeyka IM, Ross DB, et al. Phosphodiesterase type 5 is highly expressed in the hypertrophied human right ventricle, and acute inhibition of phosphodiesterase type 5 improves contractility. Circulation 2007;116:238-248.

72. Michelakis E, Tymchak W, Lien D, Webster L, Hashimoto K, Archer S. Oral sildenafil is an effective and specific pulmonary vasodilator in patients with pulmonary arterial hypertension: comparison with inhaled nitric oxide. Circulation 2002;105:2398-2403.

73. Clapp LH, Finney P, Turcato S, Tran S, Rubin LJ, Tinker A. Differential effects of stable prostacyclin analogs on smooth muscle proliferation and cyclic AMP generation in human pulmonary artery. Am J Respir Cell Mol Biol 2002;26:194-201.

74. Krause W, Krais T. Pharmacokinetics and pharmacodynamics of the prostacyclin analogue iloprost in man. Eur J Clin Pharmacol 1986;30: 61-68.

75. Tonelli AR, Haserodt S, Aytekin M, Dweik RA. Nitric oxide deficiency in pulmonary hypertension: pathobiology and implications for therapy. Pulm Circ 2013;3:20-30.

76. Morice AH, Pepke-Zaba J, Brown MJ, Thomas PS, Higenbottam TW. Atrial natriuretic peptide in primary pulmonary hypertension. Eur Respir J 1990;3:910-913.

77. Buckley MG, Marcus NJ, Yacoub MH, Singer DR. Prolonged stability of brain natriuretic peptide: importance for non-invasive assessment of cardiac function in clinical practice. Clin Sci (Lond) 1998;95:235-239.

78. Nagaya N, Ando M, Oya H, Ohkita Y, Kyotani S, Sakamaki F, Nakanishi $\mathrm{N}$. Plasma brain natriuretic peptide as a noninvasive marker for efficacy of pulmonary thromboendarterectomy. Ann Thorac Surg 2002;74:180-184, discussion 184

79. Williams MH, Handler CE, Akram R, Smith CJ, Das C, Smee J, Nair D, Denton CP, Black CM, Coghlan JG. Role of $\mathrm{N}$-terminal brain natriuretic peptide (N-TproBNP) in scleroderma-associated pulmonary arterial hypertension. Eur Heart $J$ 2006;27:1485-1494.

80. Leuchte HH, El Nounou M, Tuerpe JC, Hartmann B, Baumgartner RA, Vogeser M, Muehling O, Behr J. N-terminal pro-brain natriuretic peptide and renal insufficiency as predictors of mortality in pulmonary hypertension. Chest 2007;131:402-409.

81. Nagaya N, Nishikimi T, Uematsu M, Satoh T, Kyotani S, Sakamaki F, Kakishita M, Fukushima K, Okano Y, Nakanishi N, et al. Plasma brain natriuretic peptide as a prognostic indicator in patients with primary pulmonary hypertension. Circulation 2000;102:865-870.

82. Sztrymf B, Souza R, Bertoletti L, Jaïs X, Sitbon O, Price LC, Simonneau G, Humbert M. Prognostic factors of acute heart failure in patients with pulmonary arterial hypertension. Eur Respir J 2010;35: 1286-1293.

83. Mauritz GJ, Rizopoulos D, Groepenhoff H, Tiede H, Felix J, Eilers P, Bosboom J, Postmus PE, Westerhof N, Vonk-Noordegraaf A. Usefulness of serial N-terminal pro-B-type natriuretic peptide measurements for determining prognosis in patients with pulmonary arterial hypertension. Am J Cardiol 2011;108:1645-1650.

84. Klings ES, Machado RF, Barst RJ, Morris CR, Mubarak KK, Gordeuk VR, Kato GJ, Ataga KI, Gibbs JS, Castro O, et al.; American Thoracic Society Ad Hoc Committee on Pulmonary Hypertension of Sickle Cell Disease. An official American Thoracic Society clinical practice guideline: diagnosis, risk stratification, and management of pulmonary hypertension of sickle cell disease. Am J Respir Crit Care Med 2014;189:727-740.
85. Ghofrani HA, D'Armini AM, Grimminger F, Hoeper MM, Jansa P, Kim $\mathrm{NH}$, Mayer E, Simonneau G, Wilkins MR, Fritsch A, et al.; CHEST-1 Study Group. Riociguat for the treatment of chronic thromboembolic pulmonary hypertension. N Engl J Med 2013;369:319-329.

86. Lee DI, Kass DA. Phosphodiesterases and cyclic GMP regulation in heart muscle. Physiology (Bethesda) 2012;27:248-258.

87. Hemsén A, Ahlborg G, Ottosson-Seeberger A, Lundberg JM. Metabolism of Big endothelin-1 (1-38) and (22-38) in the human circulation in relation to production of endothelin-1 (1-21). Regul Pept 1995;55:287-297.

88. Allen SW, Chatfield BA, Koppenhafer SA, Schaffer MS, Wolfe RR, Abman SH. Circulating immunoreactive endothelin-1 in children with pulmonary hypertension: association with acute hypoxic pulmonary vasoreactivity. Am Rev Respir Dis 1993;148:519-522.

89. Giaid A, Yanagisawa M, Langleben D, Michel RP, Levy R, Shennib H, Kimura S, Masaki T, Duguid WP, Stewart DJ. Expression of endothelin-1 in the lungs of patients with pulmonary hypertension. N Engl J Med 1993;328:1732-1739.

90. Vincent JA, Ross RD, Kassab J, Hsu JM, Pinsky WW. Relation of elevated plasma endothelin in congenital heart disease to increased pulmonary blood flow. Am J Cardiol 1993;71:1204-1207.

91. Nootens M, Kaufmann E, Rector T, Toher C, Judd D, Francis GS, Rich S. Neurohormonal activation in patients with right ventricular failure from pulmonary hypertension: relation to hemodynamic variables and endothelin levels. J Am Coll Cardiol 1995;26:1581-1585.

92. Montani D, Souza R, Binkert C, Fischli W, Simonneau G, Clozel $M$, Humbert M. Endothelin-1/endothelin-3 ratio: a potential prognostic factor of pulmonary arterial hypertension. Chest 2007; 131:101-108.

93. Rubens C, Ewert R, Halank M, Wensel R, Orzechowski HD, Schultheiss HP, Hoeffken G. Big endothelin-1 and endothelin-1 plasma levels are correlated with the severity of primary pulmonary hypertension. Chest 2001;120:1562-1569.

94. Silva Marques J, Martins SR, Calisto C, Gonçalves S, Almeida AG, de Sousa JC, Pinto FJ, Diogo AN. An exploratory panel of biomarkers for risk prediction in pulmonary hypertension: emerging role of CT-proET-1. J Heart Lung Transplant 2013;32:1214-1221.

95. Hocher B, Schwarz A, Slowinski T, Bachmann S, Pfeilschifter J, Neumayer $\mathrm{HH}$, Bauer $\mathrm{C}$. In-vivo interaction of nitric oxide and endothelin. J Hypertens 2004;22:111-119.

96. Verhaar MC, Strachan FE, Newby DE, Cruden NL, Koomans HA, Rabelink TJ, Webb DJ. Endothelin-A receptor antagonist-mediated vasodilatation is attenuated by inhibition of nitric oxide synthesis and by endothelin-B receptor blockade. Circulation 1998;97:752-756.

97. Hampole CV, Mehrotra AK, Thenappan T, Gomberg-Maitland M, Shah SJ. Usefulness of red cell distribution width as a prognostic marker in pulmonary hypertension. Am J Cardiol 2009;104:868-872.

98. Rhodes CJ, Wharton J, Howard LS, Gibbs JS, Wilkins MR. Red cell distribution width outperforms other potential circulating biomarkers in predicting survival in idiopathic pulmonary arterial hypertension. Heart 2011;97:1054-1060.

99. Anker SD, Doehner W, Rauchhaus M, Sharma R, Francis D, Knosalla C Davos CH, Cicoira M, Shamim W, Kemp M, et al. Uric acid and survival in chronic heart failure: validation and application in metabolic, functional, and hemodynamic staging. Circulation 2003; 107:1991-1997. 